\title{
Role of metal oxide nanoparticles in histopathological changes observed in the lung of welders
}

\author{
Pascal Andujar ${ }^{1,2,3 \dagger}$, Angélique Simon-Deckers ${ }^{2,4 \dagger}$, Françoise Galateau-Sallé5, ${ }^{5,6}$, Barbara Fayard ${ }^{4}$, Gregory Beaune ${ }^{7,8,9}$, \\ Bénédicte Clin ${ }^{6,10}$, Marie-Annick Billon-Galland ${ }^{11}$, Olivier Durupthy ${ }^{7,8,9}$, Jean-Claude Pairon ${ }^{1,2,3}$, Jean Doucet ${ }^{4}$, \\ Jorge Boczkowski $i^{2,3,12}$ and Sophie Lanone $e^{1,2,3^{*}}$
}

\begin{abstract}
Background: Although major concerns exist regarding the potential consequences of human exposure to nanoparticles (NP), no human toxicological data is currently available. To address this issue, we took welders, who present various adverse respiratory outcomes, as a model population of occupational exposure to NP.

The aim of this study was to evaluate if welding fume-issued NP could be responsible, at least partially, in the lung alterations observed in welders.

Methods: A combination of imaging and material science techniques including ((scanning) transmission electron microscopy ((S)TEM), energy dispersive X-ray (EDX), and X-ray microfluorescence ( $\mu X R F)$ ), was used to characterize NP content in lung tissue from 21 welders and 21 matched control patients. Representative NP were synthesized, and their effects on macrophage inflammatory secretome and migration were evaluated, together with the effect of this macrophage inflammatory secretome on human lung primary fibroblasts differentiation.

Results: Welding-related NP ( $\mathrm{Fe}, \mathrm{Mn}, \mathrm{Cr}$ oxides essentially) were identified in lung tissue sections from welders, in macrophages present in the alveolar lumen and in fibrous regions. In vitro macrophage exposure to representative $\mathrm{NP}\left(\mathrm{Fe}_{2} \mathrm{O}_{3}, \mathrm{Fe}_{3} \mathrm{O}_{4}, \mathrm{MnFe}_{2} \mathrm{O}_{4}\right.$ and $\left.\mathrm{CrOOH}\right)$ induced the production of a pro-inflammatory secretome (increased production of CXCL-8, IL-1ß, TNF-a, CCL-2, -3, -4 , and to a lesser extent IL-6, CCL-7 and -22), and all but $\mathrm{Fe}_{3} \mathrm{O}_{4} \mathrm{NP}$ induce an increased migration of macrophages (Boyden chamber). There was no effect of NP-exposed macrophage secretome on human primary lung fibroblasts differentiation.

Conclusions: Altogether, the data reported here strongly suggest that welding-related NP could be responsible, at least in part, for the pulmonary inflammation observed in welders. These results provide therefore the first evidence of a link between human exposure to NP and long-term pulmonary effects.
\end{abstract}

Keywords: Welding, Occupational exposure, Metal oxide nanoparticle, Inflammation, Lung

\section{Background}

Nanotechnologies represent a major stake of the $21^{\text {rst }}$ century. They are aimed at conceiving, characterizing and producing materials at the scale of the billionth meter; the nanometer. These nanomaterials (among which are particles with a diameter lesser than $100 \mathrm{~nm}$ - nanoparticles, NP)

\footnotetext{
* Correspondence: Sophie.lanone@inserm.fr

${ }^{\dagger}$ Equal contributors

'Centre Hospitalier Intercommunal de Créteil, Service de Pneumologie et de Pathologie Professionnelle, 94000 Créteil, France

${ }^{2}$ INSERM, U955, Equipe 4, 94000 Créteil, France

Full list of author information is available at the end of the article
}

present new properties that make them particularly interesting to industrialists. The list of actual uses and applications for nanomaterials is already substantial, and will certainly become exponential in the next future. Such developments, in spite of potential benefits in numerous domains, i.e. in the field of nanomedicine, are accompanied by concerns regarding the potential consequences of human exposure (in the general population or in an occupational context), with particular threat at the respiratory level [1-3]. The need for toxicity evaluation is motivated by numerous studies already available in the literature demonstrating 
that animal exposure to engineered NP is followed, among other pathological manifestations, by the induction of a pulmonary inflammation, associated with lung remodelling [4-8]. However, so far, there is almost no study assessing the consequences of human exposure to manufactured NP. This point is critical since human exposure studies constitute the cornerstone of risk evaluation for health after (chronic) exposure to environmental agents, especially in the occupational context.

During their everyday occupation, welders are exposed to a complex aerosol of gases (e.g. carbon monoxide, ozone), and hazardous metal fumes composed of chain-like agglomerates of particles, with a primary size in the nanometer size range [9]. Indeed, up to $11 \%$ of the total mass, and $80 \%$ of the total number of particles emitted in welding fumes are NP [10,11]. Various adverse respiratory outcomes have been described in welders, among which inflammation and lung remodeling are largely described [12-16]. However, the underlying responsible mechanisms remain to be elucidated.

We therefore made the hypothesis that these abnormalities could result, at least partly, from an inflammatory effect directly induced by welding fume-issued NP present in the pulmonary tissue. Such hypothesis has never been studied in the literature so far, probably due to the technical challenges related to the analysis and characterization of NP tissular content in biological samples in situ. We therefore setup an original interdisciplinary study, combining the expertise of material science physicists, physico-chemists, biologists and medical doctors. A broad range of imaging and material science techniques (scanning/transmission electron microscopy (S/TEM), energy dispersive X-ray (EDX), and X-ray microfluorescence $(\mu \mathrm{XRF}))$, was used to characterize the association between lung histological modifications and the presence of NP in 21 well-documented arc welders and matched unexposed individuals. Since this analysis revealed the presence of NP in macrophages in the alveolar lumen and in areas of fibrous tissue in welders, our physico-chemist partner chemically synthesized NP representative of those identified in pulmonary tissue $\left(\mathrm{Fe}_{2} \mathrm{O}_{3}, \mathrm{Fe}_{3} \mathrm{O}_{4}, \mathrm{MnFe}_{2} \mathrm{O}_{4}\right.$ and $\left.\mathrm{CrOOH}\right)$, to investigate their effects (in combination or not with exposure to cigarette smoke, as the majority of patients were smokers) on human macrophages. These exposures were performed in combination or not with exposure to cigarette smoke, as the majority of patients were smokers. Our results show that exposure to welding-related NP induce the production of a pro-inflammatory secretrome (increased production of CXCL-8, IL-1ß, TNF- $\alpha$, CCL-2, -3, -4, and to a lesser extent IL-6, CCL-7 and -22). Moreover, all but $\mathrm{Fe}_{3} \mathrm{O}_{4}$ NP induce an increased migration of macrophages.Finally, there was no effect of macrophage pro-inflammatory secretome on human primary lung fibroblasts differentiation. These results provide therefore the first evidence of a link between human exposure to NP and long-term pulmonary effects.

\section{Results}

Clinical and histological characterization of patients

The clinical characteristics of the 42 patients included in our study are given in Table 1 . Consistent with the population studied, female were significantly less represented in the welder group as compared to controls $(\mathrm{p}=0.038)$. Otherwise, consistent with the selective matching of controls with welders, the two populations were similar for age and tobacco history.

CD68 staining revealed the presence of a higher number of macrophages in lung tissue sections from welders as compared to control patients, localized in the alveolar lumen as well as in the fibrous tissue (Figure 1). Importantly, black spots corresponding to aggregates of particles were essentially colocalized with CD68 staining suggesting a macrophagic internalization of these aggregates. The iron load, as revealed by Perls staining (Figure 1) and the quantification of siderophages (iron-laden macrophages) and ferruginous bodies (formed by macrophages) (Table 2), were significantly higher in welders as compared to control patients. Finally, lung fibrotic lesions were identified

Table 1 Clinicopathological characteristics of control and welder patients.

\begin{tabular}{|c|c|c|c|}
\hline & $\begin{array}{l}\text { Controls } \\
(n=21)\end{array}$ & $\begin{array}{l}\text { Welders } \\
(n=21)\end{array}$ & $P$ value \\
\hline Mean age (years $\pm S D$ ) & $58.6 \pm 10.8$ & $58.5 \pm 10.7$ & ns \\
\hline \multicolumn{4}{|l|}{ Gender } \\
\hline Female & $6(28.6 \%)$ & $1(4.8 \%)$ & 0.038 \\
\hline Male & $15(71.4 \%)$ & $20(95.2 \%)$ & ns \\
\hline \multicolumn{4}{|l|}{ Tobacco smoking } \\
\hline Smoking status & & & ns \\
\hline Current smokers & $9(43.0 \%)$ & $6(28.6 \%)$ & \\
\hline Former smokers & $9(43.0 \%)$ & $12(57.1 \%)$ & \\
\hline Never smokers & $3(14.0 \%)$ & $3(14.3 \%)$ & \\
\hline Cumulative consumption $(\mathrm{P}-\mathrm{Y} \pm \mathrm{SD})$ & $24.6 \pm 29.0$ & $22.2 \pm 15.2$ & ns \\
\hline Age at onset (years $\pm S D$ ) & $16.8 \pm 3.4$ & $18.3 \pm 4.2$ & ns \\
\hline Age at cessation (years $\pm S D$ ) & $51.6 \pm 14.0$ & $48.8 \pm 11.2$ & ns \\
\hline Duration (years $\pm S D$ ) & $32.6 \pm 16.7$ & $33.7 \pm 10.3$ & ns \\
\hline Duration since cessation (years $\pm S D$ ) & $5.7 \pm 9.3$ & $8.2 \pm 10.4$ & ns \\
\hline \multicolumn{4}{|l|}{ Welding fumes exposure } \\
\hline Positive occupational questionnaire & 0 & 21 & \\
\hline Age at onset (years $\pm S D$ ) & - & $19.9 \pm 7.6$ & \\
\hline Age at cessation (years $\pm \mathrm{SD}$ ) & - & $48.2 \pm 9.9$ & \\
\hline Duration (years $\pm S D$ ) & - & $27.0 \pm 9.2$ & \\
\hline Duration since cessation (years $\pm S D$ ) & - & $9.2 \pm 10.4$ & \\
\hline
\end{tabular}

ns: not significant; Max: maximum; Min: minimum; P-Y: packs-years; SD: standard deviation. 


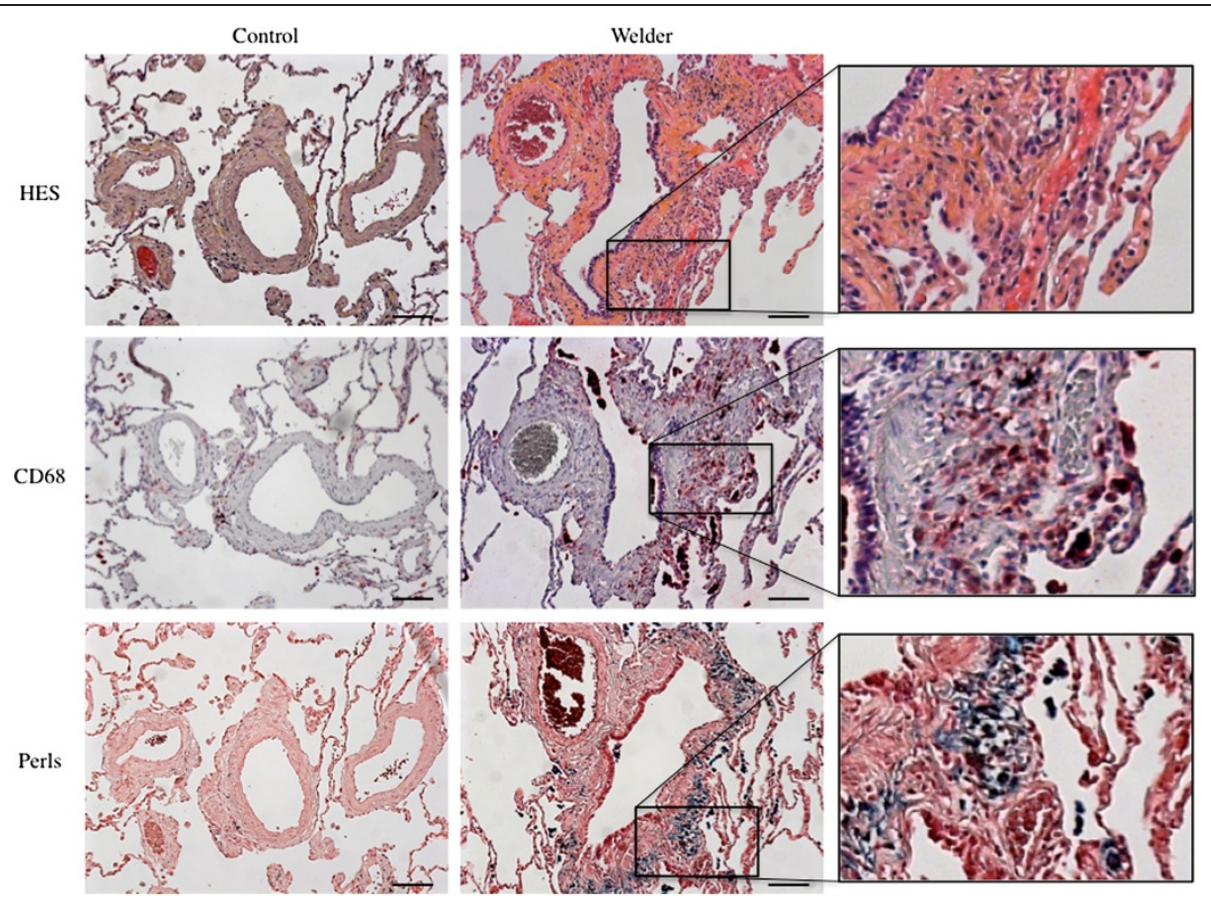

Figure 1 Histological observation of lung tissue sections. Representative optical microscopy images of lung tissue sections from a Control and a Welder. Serial sections were stained with hematoxylin-eosin-saffron (HES), CD68 or Perls. Scale bar: 100 um. Inset: higher magnification of the welder sample.

in both control and welders, but were significantly more severe in welders as compared to control patients irrespective of the histological localization (Figure 1 and Table 2). There was no difference for other respiratory lesions such as respiratory bronchiolectasis, bronchiolar dysplasia or metaplasia, or bronchiolitis between the two groups (Table 2).

\section{Patients' particle burden characterization Elemental mapping in lung tissue sections}

We first wanted to get a general overview of the elemental mapping at the global level of the tissue. To that matter, we used synchrotron-based X-ray microfluorescence ( $\mu \mathrm{XRF}$ ) and determined the spatial distribution of elements performing $100 \times 100 \mu \mathrm{m}$ maps. Figure 2A shows typical elemental $\mu$ XRF maps obtained for sulfur (S), iron (Fe), and manganese $(\mathrm{Mn})$ in control patients and welders. Since S represents a characteristic element of biological materials, the shape of the tissue can be drawn by the $\mathrm{S}$ map [17]. Using this approach, we observed a significant overload of $\mathrm{Fe}, \mathrm{Mn}$, chromium ( $\mathrm{Cr}$ ) essentially and to a lesser extent for titanium (Ti) in welders as compared to control patients (Figure 2B). This signal was essentially localized in the fibrous tissue (Figure 2), and to a lesser extent in the alveolar lumen (data not shown). Remarkably, we could observe that iron-rich zones were often co-localized with other element-rich zones, particularly $\mathrm{Mn}$ and $\mathrm{Cr}$ (Figure 2 and data not shown).

\section{$N P$ identification in lung tissue homogenates}

To determine individual exposure to asbestos bodies and non fibrous mineral particles, a mineralogical analysis of lung tissue homogenates was performed. These experiments confirmed the metallic overload in welder's lung and identified a significantly higher mass concentration of total mineral and especially metallic particles in welders as compared to control patients (Table 3). Consistent with the initial selective matching of controls with welders, the two populations were similar for asbestos exposure characteristics. Finally, in order to characterize the size and chemical nature of the particles present in the pulmonary samples, we used a combined STEM-EDX (Scanning Transmission Electron Microscopy (STEM)Energy Dispersive X-Ray (EDX)) analysis of lung tissue homogenates, and demonstrated that the particles are of nanometric size (20-25 $\mathrm{nm}$ individual diameter - STEM analysis Figure $3 \mathrm{~A}$ ), and confirmed the chemical nature ( $\mathrm{Fe}, \mathrm{Mn}, \mathrm{Cr}$ essentially) and the co-localization of the chemical signals (EDX analysis, Figure 3B).

\section{NP identification in lung tissue sections}

Following the detection of NP in the lung tissue homogenates, we questioned the identification of these NP in situ at the nanometer scale and characterized their localization in lung tissue sections from patients, especially in areas of lung remodeling. We therefore proceeded to a combined TEM-EDX analysis of lung tissue sections and observed 
Table 2 Histological analysis of lung tissue in control and welder patients

\begin{tabular}{|c|c|c|c|}
\hline & $\begin{array}{l}\text { Controls } \\
(\mathrm{n}=21)\end{array}$ & $\begin{array}{l}\text { Welders } \\
(n=21)\end{array}$ & $P$ value \\
\hline \multicolumn{4}{|l|}{ Siderophages } \\
\hline Presence (n patients) & 10 & 17 & 0.024 \\
\hline $\begin{array}{l}\text { Number (Mean semi-quantitative } \\
\text { score } \pm \text { SD) }\end{array}$ & $0.71 \pm 0.90$ & $1.57 \pm 1.17$ & 0.019 \\
\hline \multicolumn{4}{|l|}{ Ferruginous bodies (n patients) } \\
\hline Presence (n patients) & 6 & 16 & 0.002 \\
\hline $\begin{array}{l}\text { Number (Mean semi-quantitative } \\
\text { score } \pm S D)^{b}\end{array}$ & $0.43 \pm 0.81$ & $1.81 \pm 1.57$ & 0.002 \\
\hline \multicolumn{4}{|l|}{$\begin{array}{l}\text { Fibrotic lesions } \\
\text { (Number of patients) }\end{array}$} \\
\hline Peribronchiolar & 16 & 20 & ns \\
\hline Perivascular & 14 & 20 & 0.018 \\
\hline Paraseptal & 8 & 10 & ns \\
\hline Alveolar & 3 & 5 & ns \\
\hline Diffuse interstitial & 6 & 5 & ns \\
\hline Pleural & 4 & 2 & ns \\
\hline \multicolumn{4}{|l|}{ Severity of fibrosis ${ }^{a}$} \\
\hline \multicolumn{4}{|l|}{ (Mean semi-quantitative score \pm SD) } \\
\hline Global & $2.29 \pm 1.59$ & $3.91 \pm 1.51$ & 0.003 \\
\hline Peribronchiolar & $1.10 \pm 0.77$ & $1.86 \pm 0.85$ & 0.005 \\
\hline Perivascular & $1.05 \pm 0.92$ & $1.81 \pm 0.81$ & 0.010 \\
\hline Alveolar and peribronchiolar & $1.57 \pm 1.12$ & $2.67 \pm 1.16$ & 0.004 \\
\hline \multicolumn{4}{|l|}{ Other respiratory lesions } \\
\hline Bronchiolectasis & 16 & 13 & ns \\
\hline Bronchiolar metaplasia & 2 & 0 & ns \\
\hline Bronchiolar dysplasia & 1 & 5 & ns \\
\hline $\begin{array}{l}\text { Respiratory Bronchiolitis - Intertitial } \\
\text { Lung Disease }\end{array}$ & 10 & 10 & ns \\
\hline Desquamative intertitial pneumonitis & 12 & 9 & ns \\
\hline Endogenous Lipoid Pneumonitis & 1 & 3 & ns \\
\hline
\end{tabular}

ns: not significant; SD: standard deviation.

${ }^{a}$ Semi-quantitative score [4 classes $=0$ : absent; 1 : rare; 2 : frequent; 3 :

important]. Adapted from Roggli classification [54].

${ }^{b}$ Semi-quantitative score [5 classes =0: 0/slide; $1:<5 /$ slide; 2 : 5 to $10 /$ slide; 3 : 10 to $50 /$ slide ; 4 : > 50/slide].

that, in comparison with control patients, large quantities of NP were localized in macrophages residues, and was present in the fibrous tissue of welders (Figure 4). In accordance with the results obtained in lung tissue homogenates, these NP presented a spherical shape, and a diameter centered around $20-25 \mathrm{~nm}$. The chemical nature of the complex metal oxide NP in the welders lungs were mainly $\mathrm{Fe}, \mathrm{Cr}$ and/or Mn (and aluminium (Al), silicium ( $\mathrm{Si}$ ), and nickel (Ni) to a lesser extent), whereas it was essentially $\mathrm{Al}$ and $\mathrm{Si}$ NP in the control patients (data not shown).

Overall, these different material science techniques allow us to demonstrate the presence of $\mathrm{Fe}, \mathrm{Cr}$ and/or
Mn NP in situ in lung tissue from welders, especially in macrophages.

\section{Synthesis of representative NP}

In order to answer the question whether the metal NP identified above have a causal role in the development of pulmonary alterations observed in welders, we next chemically synthesized $4 \mathrm{NP}$ representative of those found in lung tissue samples; $\mathrm{Fe}_{2} \mathrm{O}_{3}, \mathrm{Fe}_{3} \mathrm{O}_{4}, \mathrm{MnFe}_{2} \mathrm{O}_{4}$ and $\mathrm{CrOOH}$. As shown in Figure 5, all NP were spherical and presented an average diameter of $25 \mathrm{~nm}\left(\mathrm{Fe}_{2} \mathrm{O}_{3}, \mathrm{Fe}_{3} \mathrm{O}_{4}, \mathrm{MnFe}_{2} \mathrm{O}_{4}\right)$ or $15 \mathrm{~nm}(\mathrm{CrOOH})$ (Figure 5A-D). The NP nature was verified by $\mathrm{X}$-ray diffraction spectra (Figure $5 \mathrm{E}-\mathrm{H}$ ).

\section{The in vitro effect of the synthesized NP on the macrophage secretome}

Because NP identified in lungs from welders were in macrophages, we first evaluated the effects of human macrophage exposure to the chemically synthesized representative NP in terms of inflammatory secretome. These experiments revealed the secretion of significantly increased amounts of IL-1ß, TNF- $\alpha$, CCL-2, -3, -4, and lesser levels of IL-6, CCL-7 and -22 in macrophages exposed to $25 \mu \mathrm{g} / \mathrm{cm}^{2}$ (a concentration representative of occupational exposure [18]) of all but $\mathrm{Fe}_{3} \mathrm{O}_{4} \mathrm{NP}$ as compared to unexposed cells (Figure 6). Moreover, CXCL-8 production was also significantly higher in macrophages exposed to all but $\mathrm{Fe}_{3} \mathrm{O}_{4} \mathrm{NP}$ at the dose of $5 \mu \mathrm{g} / \mathrm{cm}^{2}$, and to all NP when used at $25 \mu \mathrm{g} / \mathrm{cm}^{2}$ (Figure 6). No modification of the secretion of IL-4, $-5,-10,-12,-13$, PDGFAA, PDGF-BB, or TGF- $B$ was detected, whatever the NP utilized (data not shown). MMP-1 and MMP-7 levels in cell culture supernatants were significantly increased in $\mathrm{MnFe}_{2} \mathrm{O}_{4}$-treated macrophages as compared to unexposed cells $\left(25 \mu \mathrm{g} / \mathrm{cm}^{2}\right.$, Additional file 1: Figure S1). Moreover, exposure to $\mathrm{Fe}_{2} \mathrm{O}_{3} \mathrm{NP}$ at $25 \mu \mathrm{g} / \mathrm{cm}^{2}$ induced an increased production of MMP-7 and TIMP-2 as compared to unexposed cells (Additional file 1: Figure S1). Finally, no modification of the expression of MMP-2, -9, -10, TIMP$1,-3$, and -4 was observed irrespective of NP exposure (data not shown).

Since welding fumes contain a mixture of NP, we next questioned whether a mix of the most representative NP could have a synergistic effect on the macrophage secretome. These experiments showed that exposure of macrophages to the $(1: 1: 1: 1)$ combination of $\mathrm{Fe}_{2} \mathrm{O}_{3}, \mathrm{Fe}_{3} \mathrm{O}_{4}$, $\mathrm{MnFe}_{2} \mathrm{O}_{4}$ and $\mathrm{CrOOH}$ NP didn't produce any synergistic effect in terms of cytokine or MMP/TIMP secretion (Figure 6 and Additional file 1: Figure S1). Finally, as the majority of the welders were smokers, we analyzed if the combined exposure to NP and cigarette smoke could have a synergistic pro-inflammatory effects. These exposures did not demonstrate any synergistic effect of 

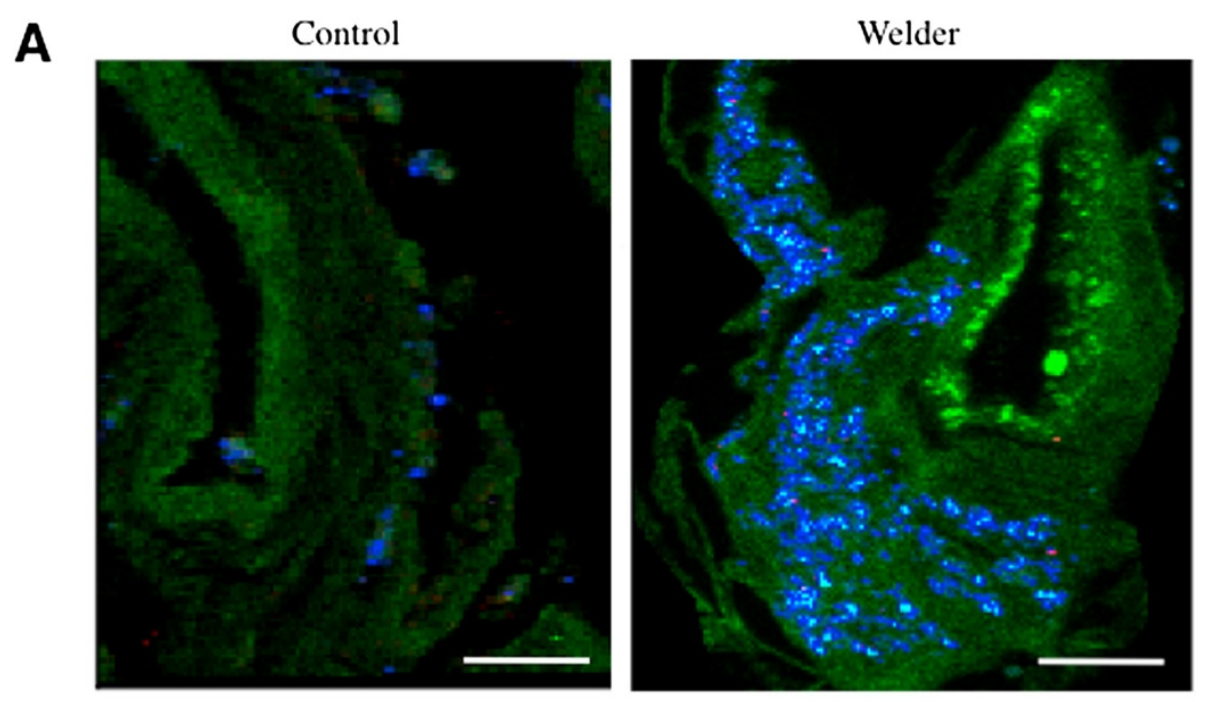

B

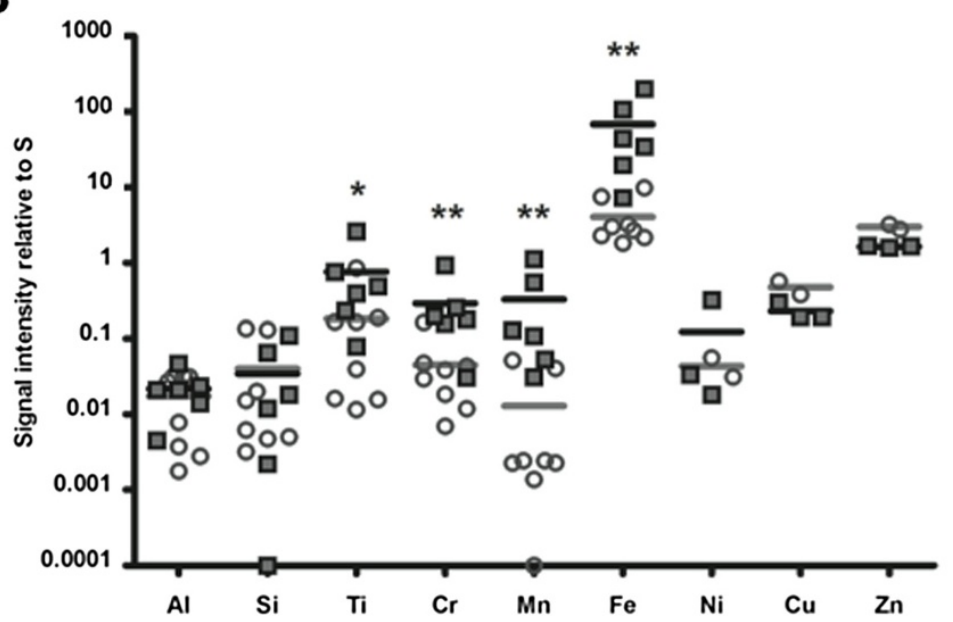

Figure 2 Elemental mapping of lung tissue sections. A: Representative elemental map obtained by X-ray micro-fluorescence ( $\mu$ XRF) in a Control and a Welder. Signal of sulphur: green. Signal of iron: blue. Signal of manganese: red. Scale bar: $100 \mu$ m. For each element, fluorescence intensities are proportional to the total amount of element. B: Quantification of the signal obtained for each element, given as a ratio to that of sulphur. *: $p<0.05$ vs Control, **: $p<0.01$ vs Control, $n=6-8$ per group. Open circles: Controls (grey horizontal bar: mean value). Black squares: Welders (black horizontal bar: mean value).

cigarette smoke in macrophages response to NP exposure (Additional file 2: Figure S2 and Additional file 3: Figure S3).

Effect of macrophage secretome on macrophage migration Following the identification of the increased number of macrophages in welders lung, the consequence of an autocrine effect of macrophage secretome on the migration capacity of these cells was investigated. Concurrently with our previous data, the secretome obtained from all exposures with the exception of the $\mathrm{Fe}_{3} \mathrm{O}_{4}$ NP-exposed macrophages was able to activate macrophage migration (Additional file 4: Figure S4).

\section{Expression of pro-inflammatory cytokines in lung tissue sections}

To further scrutinize the clinical relevance of the macrophage secretome induction by NP exposure, a series of immuno-histochemistry experiments were performed in lung tissue sections from control and welders, for a subset of cytokines that were highly produced by NPexposed macrophages. As shown in Figure 7 and quantified in Table 4, the expression of IL-1ß, TNF- $\alpha$ and CCL-3 was significantly higher in lung sections from welders as compared to controls, whereas no difference was observed for CCL-2 expression. For the 3 positive 
Table 3 Mineralogical analysis and asbestos exposure quantification of lung tissue homogenates in control and welder patients

\begin{tabular}{|c|c|c|c|}
\hline & $\begin{array}{l}\text { Controls } \\
(n=21)\end{array}$ & $\begin{array}{c}\text { Welders } \\
(n=21)\end{array}$ & $P$ value \\
\hline Dry lung tissue weight $(\mathbf{m g})($ Mean $\pm S D)$ & $24.8 \pm 7.6$ & $21.4 \pm 8.0$ & ns \\
\hline \multicolumn{4}{|c|}{ Mineral particle concentration in lung tissue (number of particles $\times 10^{7}$ per g; Mean \pm SD) } \\
\hline Total & $70.2 \pm 84.3$ & $155.9 \pm 148.8$ & 0.012 \\
\hline Metallic & $17.3 \pm 22.7$ & $73.9 \pm 66.0$ & 0.0005 \\
\hline Non metallic & $48.8 \pm 61.1$ & $80.9 \pm 105.1$ & ns \\
\hline \multicolumn{4}{|l|}{ Asbestos exposure } \\
\hline Positive occupational questionnaire & 8 & 8 & \\
\hline AB/g dry lung tissue (median) & 23,667 & 4,001 & ns \\
\hline [Min-Max] & {$[165-437,175]$} & {$[685-44,370]$} & ns \\
\hline$>1000 \mathrm{AB} / \mathrm{g}$ dry lung tissue $(\mathrm{n})$ & 7 & 8 & ns \\
\hline
\end{tabular}

AB: asbestos bodies; SD: standard deviation.

cytokines, and in accordance with NP tissue localization, the staining could be observed in macrophages located in the alveolar lumen as well as in fibrous regions.

\section{Effect of macrophage secretome on human lung pulmonary fibroblast activation}

Since lung from welders contained an increased number of macrophages not only in alveolar lumen but also in areas of fibrosis, and since NP induced an inflammatory secretome in macrophages in vitro that can be similarly detected in situ in macrophages localized in the same areas, we next investigated the effects of macrophage secretome on fibroblasts to myofibroblasts differentiation and fibroblasts proliferation. Since, as previously mentioned, the majority of the welders were smokers, these experiments were performed in lung fibroblasts from both non smokers and smokers, to address the specific role of cigarette smoke exposure as well as that of NP. Exposure of lung fibroblasts to the secretome of NPexposed macrophages revealed neither a modification in their $\alpha$-smooth muscle actin ( $\alpha$-SMA) staining (Additional file 5: Figure S5A, B and data not shown), nor a change in their proliferation rate over 48 hours (Additional file 5: Figure S5C and data not shown) irrespective of the individual being a smoker or not. Moreover, no modification of the secretion of TGF- $\beta$ by fibroblasts exposed to macrophage secretome was observed (data not shown).

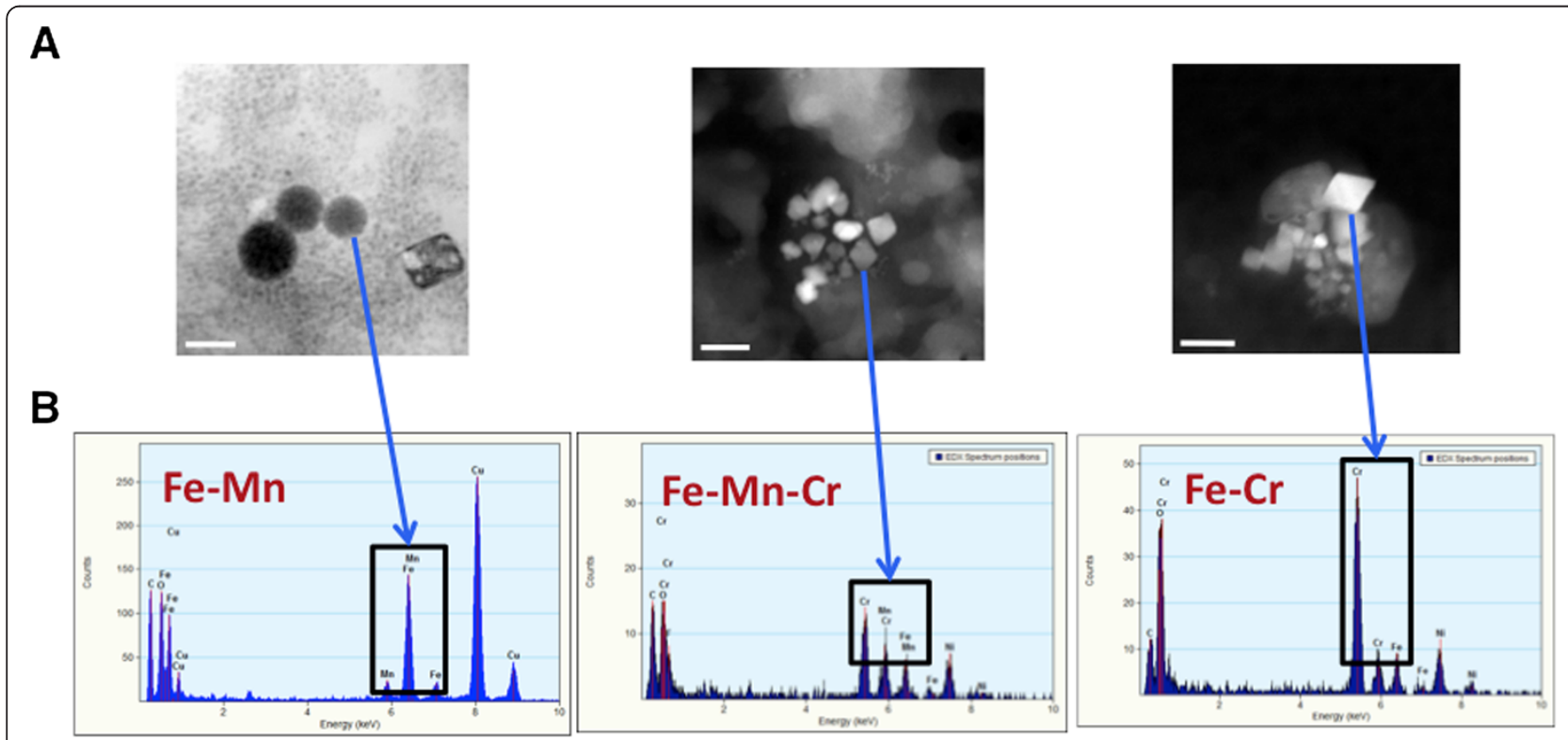

Figure 3 Identification of NP in lung tissue homogenates. A: Typical STEM images obtained in sodium hypochlorite-digested lung tissue samples from welders. Scale bar: $50 \mathrm{~nm}$. B: EDX spectra of individual NP detected by STEM. 
A

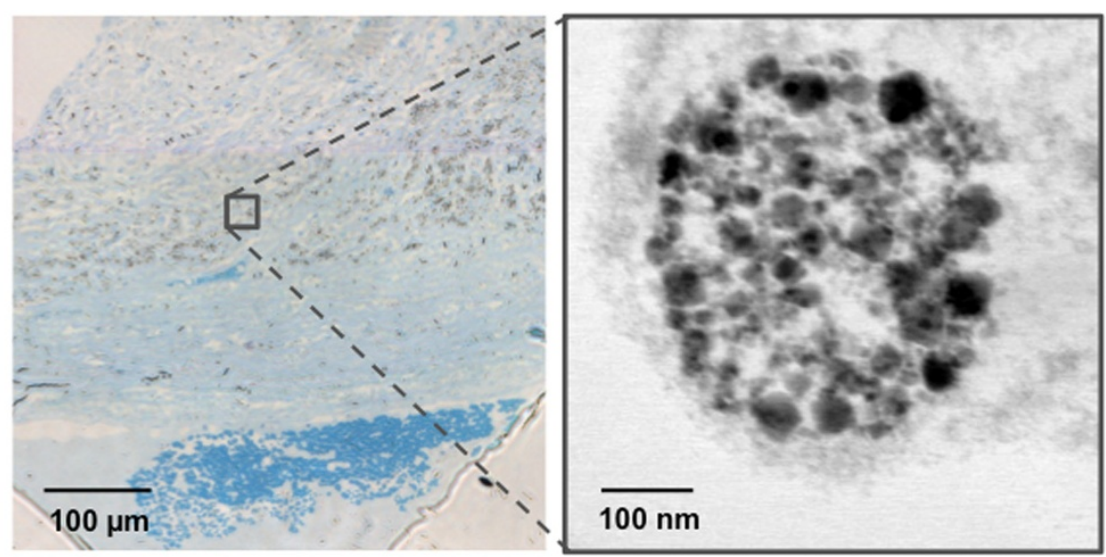

B

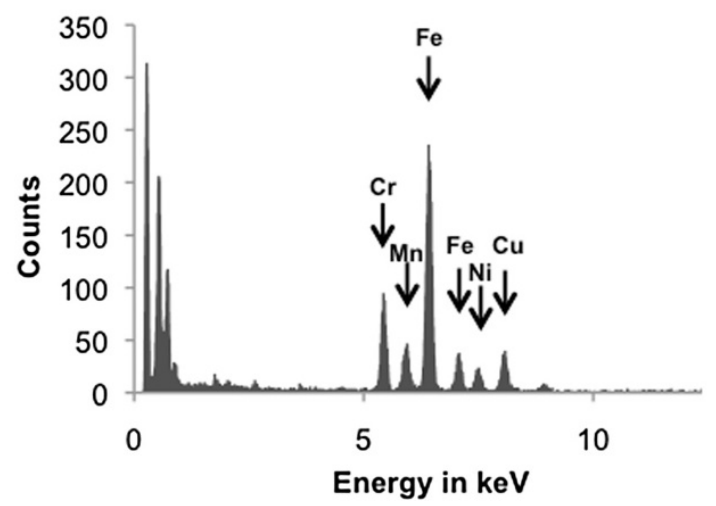

Figure 4 Identification of NP in lung tissue sections. A: Representative optical microscopy image of a thin section (Azur II staining) of a welder. Inset: higher magnification of a macrophage-containing fibrous region, observed by TEM. B: Representative EDX spectrum of individual NP detected by TEM.

\section{Discussion}

In this study a combination of imaging and material science techniques were utilized to comprehensively scrutinize lung tissue samples, and for the first time thoroughly characterize welding-related NP in situ in lung tissue from welders. Moreover, given the tissue localization and the effects of such NP on macrophages in vitro, the data here strongly suggests that these NP could be responsible at least in part for the pulmonary inflammation observed in welders.

To the best of our knowledge, only a very limited number of studies has been performed in welders, identifying the presence of nanoparticles [19-22]. However, although using the valuable combined (S)TEM/EDX analysis as developed by Abraham and colleagues [23-26], these studies present some major limitations, such as a small number of patient(s) $[19,21]$, or a very specific exposure (aluminum factory, not representative of the general occupational exposure of welders) [20]. Our study in the other hand is the first to provide persuasive evidence not only of the presence of NP in situ in human lung tissue samples, but also the identification of their chemical composition. As expected given the occupational exposure of the patients, iron was the major element present in excess in the arc welders evaluated in our study. Indeed, if the exact chemical composition of welding fumes is dependent on the material being welded and the electrode, in manual arc welding fumes and in accordance with our findings, the elemental composition is predominantly iron present as metal oxide $\mathrm{NP}$ of the form $(\mathrm{M}, \mathrm{Fe})_{3} \mathrm{O}_{4}$, where $\mathrm{M}$ may be substituted for $\mathrm{Mn}$ and $\mathrm{Cr}$ essentially [9,27-30]. These results led us to chemically synthesize 4 different NP, representative of those found in the welders lungs; 2 speciation of pure iron oxide $\left(\mathrm{Fe}_{2} \mathrm{O}_{3}\right.$ and $\left.\mathrm{Fe}_{3} \mathrm{O}_{4}\right)$, a mixed $\mathrm{Mn} / \mathrm{Fe}$ oxide $\left(\mathrm{MnFe}_{2} \mathrm{O}_{4}\right)$, and an oxyhydroxide $\mathrm{CrOOH}$ NP. We chose to generate both $\mathrm{Fe}_{2} \mathrm{O}_{3}$ and $\mathrm{Fe}_{3} \mathrm{O}_{4}$ because, although our data didn't provide any evidence of the exact speciation of these iron oxides, such species have been largely described in the literature regarding welding fume chemical composition $[9,27,30]$. Moreover, given the observed co-localization of $\mathrm{Mn}$ and Fe signals in 

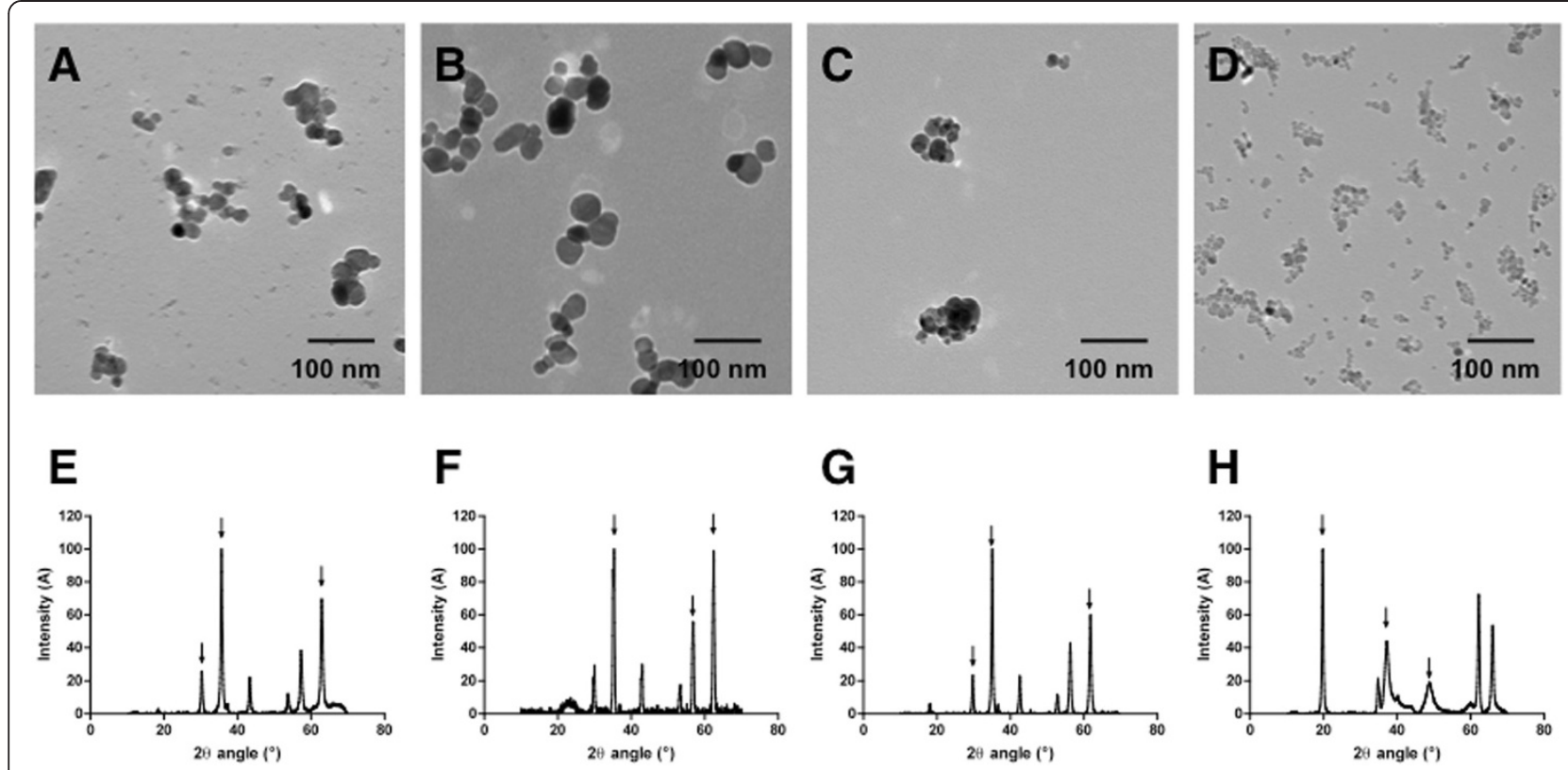

Figure 5 Characterization of welding-representative NP. A-D: Representative TEM images of $\mathrm{Fe}_{2} \mathrm{O}_{3}$ (A), $\mathrm{Fe}_{3} \mathrm{O}_{4}$ (B), $\mathrm{MnFe} \mathrm{O}_{4}$ (C) and $\mathrm{CrOOH}$ (D) NP. E-H: Corresponding XRD spectra obtained for each NP. The three important $2 \theta$ values (arrow) of XRD spectra were use to identified synthesized $\mathrm{NP}$ as $\mathrm{Fe}_{2} \mathrm{O}_{3}(\mathbf{E}), \mathrm{Fe}_{3} \mathrm{O}_{4} \mathbf{( F )}, \mathrm{MnFe}_{2} \mathrm{O}_{4}(\mathbf{G})$ and $\mathrm{CrOOH}(\mathbf{H})$.

our lung samples as well as data from the literature [31], we chose to generate $\mathrm{MnFe}_{2} \mathrm{O}_{4} \mathrm{NP}$ as a mix metal oxide relevant to welding fume exposure. Finally, we chose to generate $\mathrm{CrOOH}$ oxyhydroid NP that present the same + III oxidation state and particle size in the same range as the other NP. Indeed, $\mathrm{FeCr} 2 \mathrm{O} 4$ particles can be synthesized but not at the nanoscale, making them of no interest for our study.

We demonstrated that exposure of macrophages to the synthesized representative NP results in the production of a pro-inflammatory secretome, by itself able to further activate the migration of macrophages in vitro. Although we did not conduct experiments to identify the specific protein(s) responsible for the activation of macrophage migration, several candidates present in macrophage pro-inflammatory secretome can be proposed; CCL-2, CCL-3, CXCL-8, as they directly act as efficient monocyte, lymphocyte and neutrophil chemoattractant [32-34]. Moreover, it is important to underline that mediators such as TNF- $\alpha$ and IL-1ß, highly secreted by macrophages in response to NP (Figure 4), could also participate in the perpetuation of inflammation initiated by NP exposure since they have been shown to further induce the expression of chemotactic cytokines such as CCL-2, -3 and CXCL-2, thus sustaining the pulmonary increases of neutrophils, lymphocytes, and macrophages [32,35,36]. Similar events have been described in BAL fluid from animals exposed to welding fumes or other dusts [5,13,37-42]. These events could happen in welders, given that we were able to detect some of these cytokines in lung tissue sections of the patients analyzed in our study. Not all NP produced the same effects in vitro, although utilized at the same mass concentration; $\mathrm{Fe}_{3} \mathrm{O}_{4}$ was overall the less reactive NP, particularly as compared to $\mathrm{Fe}_{2} \mathrm{O}_{3}$, which underlines the importance of NP speciation in their individual effects. Such differences in NP effects could be related to different degrees of solubility. However, observation by TEM of 3 months old NP suspensions revealed that all nanoparticles appear similar to those observed in the initial suspension, except for $\mathrm{MnFe}_{2} \mathrm{O}_{4}$ nanoparticles that appear slightly amorphous at their surface (data not shown). This most probably indicates a very small or no solubility at all of the nanoparticle of interest, as we should have observed a diminution of the nanoparticle diameter in case of solubility. This is also in accordance with data from literature demonstrating that iron and chromium oxides are very poorly soluble in water [43-47]. Interestingly, we did not observe any synergistic effect between NP when used as a 1:1:1:1 mix, suggesting a common biological mechanism of action. An LPS contamination of our NP could have been responsible for the M1-like phenotype of THP-1 macrophages in vitro [48]. However, the endotoxin content of the NP solutions was evaluated and we didn't measure any detectable levels of endotoxin, thus ruling out endotoxin contamination (data not shown). Altogether, our data strongly suggests a role for the NP identified in lung tissue samples from welders in the development of their pulmonary inflammation. This could have great implications in other populations of workers occupationally exposed to NP. 


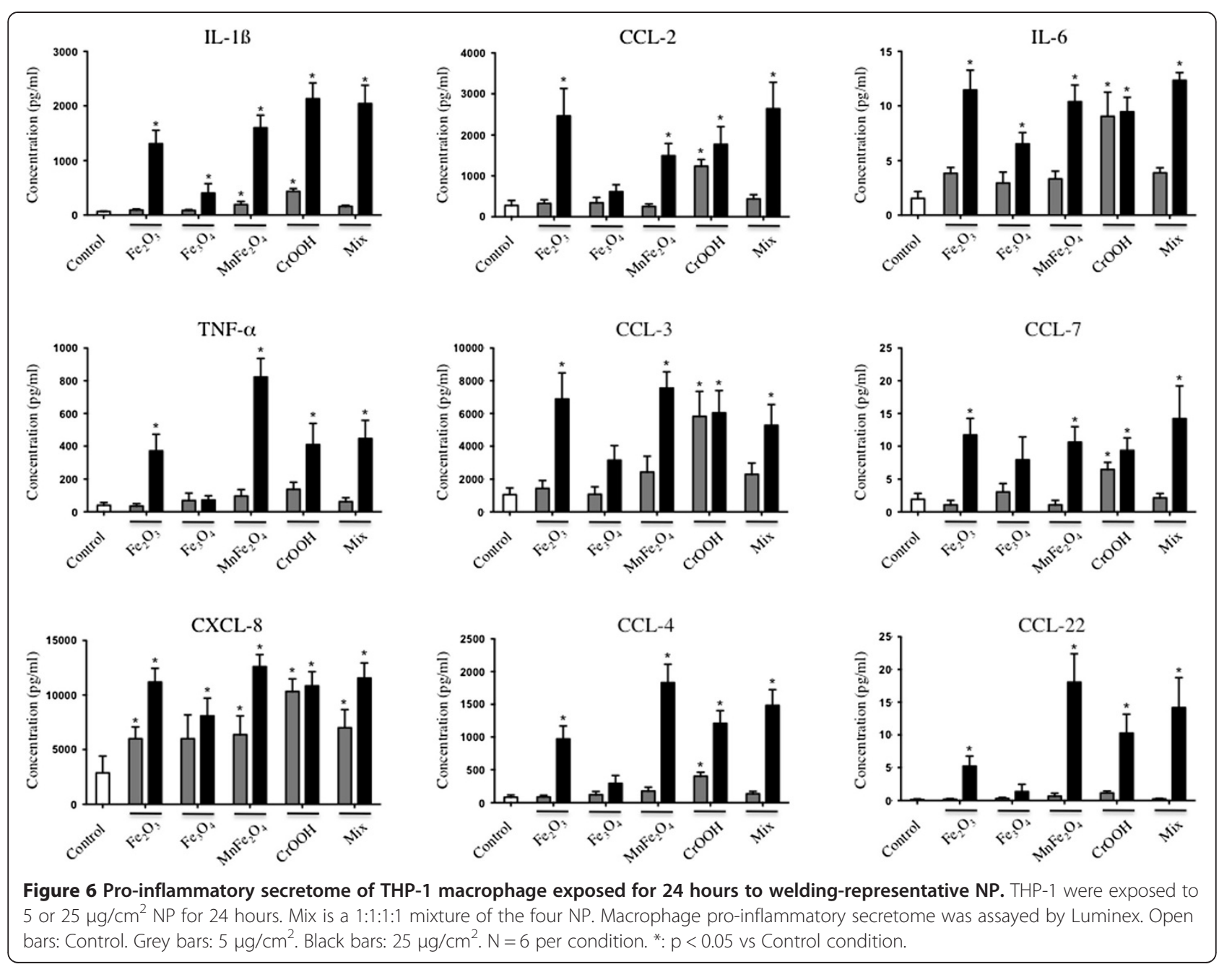

As stated previously, the majority of the patients studied here were either current or former smokers which could have been troublesome during the interpretation of the data. Indeed, the presence of NP has been described in cigarette smoke [49]. Therefore, the welding origin of the NP found in welders lungs could be questioned. However, only $\mathrm{Al}$ and $\mathrm{Si} \mathrm{NP}$ were observed in control patients, irrespective of their smoking status, thus ruling out a potential misinterpretation of the findings related to cigarette smoke NP. Moreover, we did not observe any synergistic effect between cigarette smoke and metallic NP exposure in vitro. Although we observed only a limited effect of cigarette smoke exposure alone, this underlines the unique effect of welding-related NP.

NP-loaded macrophages were present not only in the alveolar lumen but also in the fibrous tissue of lung tissue sections from welders. In chronic repetitive injury situations leading to fibrosis development (such as welding fume exposure in an occupational context), it is known that inflammation invariably precedes fibrosis [50]. Since we detected a pro-inflammatory secretome in macrophages exposed to NP, we hypothesized that this secretome could induce fibroblast differentiation into myofibroblasts. Indeed, myofibroblasts represent the major cellular effector of fibrogenic reactions, and fibroblasts have long been considered as the only cell type of origin for myofiboblasts [50]. However, the data here did not indicate any myofibroblastic differentiation. These findings could be explained by the absence of TGF- $\beta$ production in NP-exposed macrophage supernatant, as TGF- $\beta$ is the main cytokine involved in fibroblasts differentiation [50]. Moreover, one can't rule out the influence of kinetic aspects of our experimental set-up, where macrophages were exposed for 48 hours, leading to a M1-like pro-inflammatory phenotype, without the possibility of developing a later M2 phenotype, where macrophages could act as the primary effectors of later stages of repair and/or later proliferative and remodeling phases. Beside fibroblasts, fibrocytes and epithelial cells have also been described as sources of myofibroblasts $[50,51]$. Their response to supernatant from NP-exposed macrophages could have been interesting to evaluate given the presence of specific cytokines such as CCL-2 and 


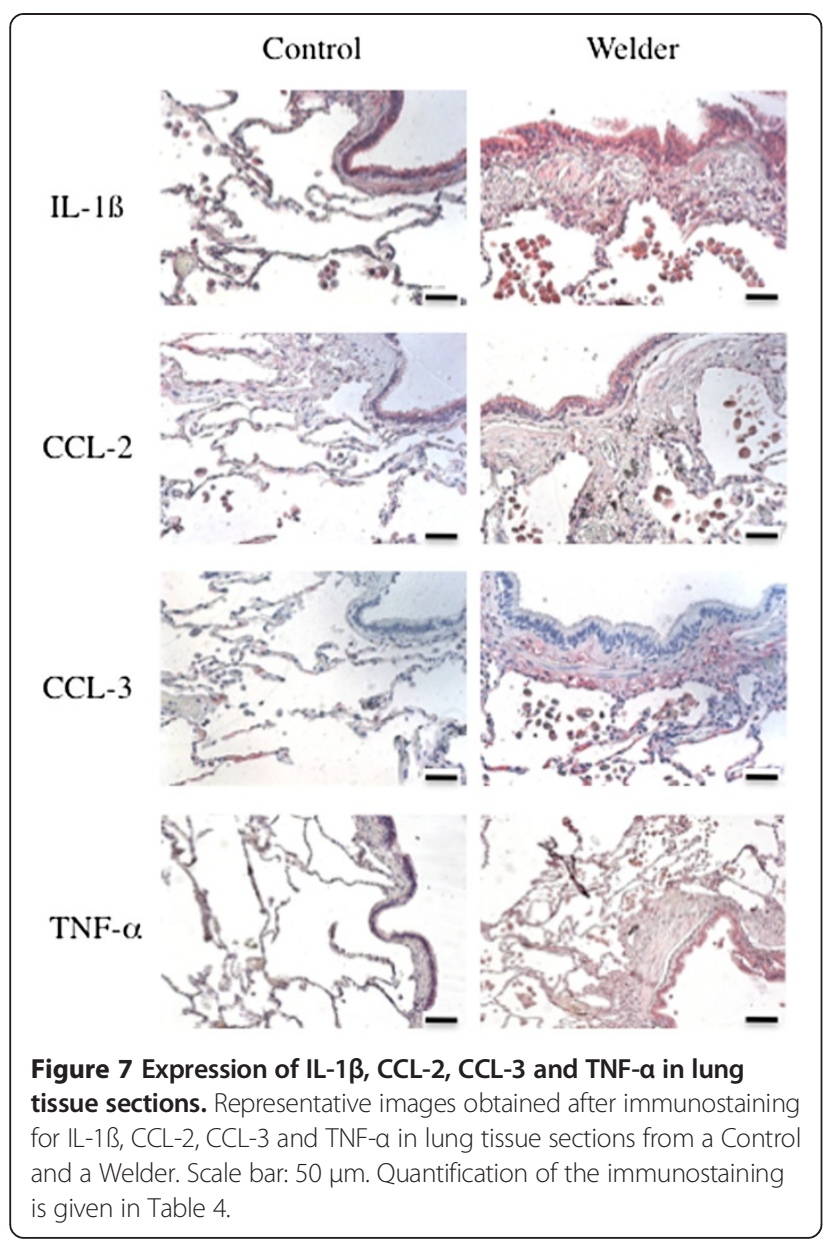

CCL-3. Indeed, CCL-2 is a chemoattractant for fibrocytes [52], and CCL-3 has been involved in bleomycin-induced recruitment of bone marrow-derived macrophages and fibrocytes, and the subsequent development of pulmonary fibrosis [53]. This should deserve further studies.

\section{Conclusion}

In this study, thanks to the extensive physico-chemical characterization of lung tissue sample from welders, we

Table 4 Semi-quantitative score of cytokine expression in lung tissues

\begin{tabular}{lccc}
\hline & $\begin{array}{c}\text { Controls } \\
(\mathbf{n}=\mathbf{7})\end{array}$ & $\begin{array}{c}\text { Welders } \\
(\mathbf{n}=\mathbf{1 0})\end{array}$ & P value \\
\hline IL-1 $\beta$ & $1.71 \pm 1.11$ & $3.60 \pm 0.52$ & 0.002 \\
TNF-a & $0.83 \pm 0.75$ & $3.43 \pm 1.81$ & 0.042 \\
CCL2 & $1.86 \pm 1.57$ & $2.00 \pm 1.31$ & $n$ ns \\
CCL3 & $1.29 \pm 1.25$ & $3.00 \pm 1.00$ & 0.015 \\
\hline
\end{tabular}

Each value is given as a mean semi-quantitative score ${ }^{a} \pm$ SD. ns: not significant; SD: standard deviation.

${ }^{a}$ Semi-quantitative score [0: 0 positive cells/slide; $1: 1-5$ positive cells/slide; 2 : 5-10 positive cells/slide; 3: 10-50 positive cells/slide; 4: >50 positive cells/slide]. evidenced the presence of welding-related NP in situ. Moreover, our data strongly suggest that these NP could participate in the pulmonary alterations observed in welders. These findings provide the first evidence of a link between human exposure to NP and long-term pulmonary effects.

\section{Methods}

Please refer to online data supplement (Additional file 6) for additional details.

\section{Patients}

Non-tumoral lung tissue sample from 21 arc-welders and matched 21 control patients benefiting surgical resection for primary non-small-cell lung cancer were removed and utilized in the study. All patients were subjected to a thorough occupational questionnaire. All welders had preponderantly arc-welding activities during their whole career, one third of them also performed torch and/or braze welding. The subjects essentially used Tungsten Inert Gas (TIG), Metal Inert Gas (MIG), Metal Active Gas (MAG), and/or Shielded Metal Arc (SMAW), Metal Manual Arc Welding (MMA) techniques. They welded mainly mild steel and/or stainless steel metal pieces, essentially in the following domains of activities; shipbuilding (53\%), automotive industry (14\%), and sheet metal work (24\%). The study was approved by our institutional review board for human studies.

\section{Histological and immunohistochemical analysis}

Paraffin-embedded lung tissue sections $(5 \mu \mathrm{m})$ were stained with hematoxylin-eosin-saffron (HES) or Perls prussian blue. The localization and severity of fibrosis was evaluated via a semi-quantitative score adapted from Roggli [54]. The presence of other respiratory lesions as well as siderophages and ferruginous bodies were quantified. Mineralogical analysis and quantification of asbestos exposure were performed as previously described [55]. Additionally, immunohistochemical (IHCh) analyses were performed on the deparaffinized tissue sections.

\section{Characterization of pulmonary NP content \\ Elemental mapping in lung tissue sections}

$\mathrm{X}$-ray microfluorescence $(\mu$-XRF) was used to determine the elemental mapping in lung tissue sections. These experiments were performed at the European Synchrotron Radiation Facility (Grenoble, France), on ID21 and ID13 beamlines, at 7.2 and $12.5 \mathrm{keV}$ edges respectively.

\section{NP identification in lung tissue homogenates}

Lung tissue homogenates were observed using a FEI Tecnai F20 STEM at $200 \mathrm{kV}$, equipped with an EDX spectrometer. 


\section{$N P$ identification in lung tissue sections}

Paraffin-embedded lung tissue sections were deparaffined and further embedded in Epon resin. Thin sections $(300 \mathrm{~nm})$ were stained with Azur II dye and observed via optical microscopy. In addition ultrathin sections (70 nm) counterstained with lead citrate and uranyl acetate were observed using a JEOL1400-TEM at $120 \mathrm{kV}$, or a FEI Tecnai F20-STEM at $200 \mathrm{kV}$, equipped with EDX spectrometer for elemental analysis of the identified NP.

\section{Synthesis of representative NP}

$\mathrm{Fe}_{2} \mathrm{O}_{3}, \mathrm{Fe}_{3} \mathrm{O}_{4}, \mathrm{MnFe}_{2} \mathrm{O}_{4}$ and $\mathrm{CrOOH} \mathrm{NP}$ were synthesized in aqueous solution using the micro-waved-assisted sol-gel method. Particle nature was determined by X-Ray diffraction (XRD), and their size and shape were evaluated using the Debye-Scherrer equation on several diffraction peaks, together with an analysis of TEM images.

\section{Exposure of human macrophages to NP Cell culture}

Human monocytic THP-1 cells were cultured as previously described [56], and were exposed to $1-25 \mu \mathrm{g} / \mathrm{cm}^{2}$ NP suspensions for 24 hours (non-cytotoxic doses, data not shown). After exposure, the cell supernatant was recovered and centrifuged at $10000 \mathrm{~g}$ for 15 minutes to eliminate any NP contamination.

\section{Luminex analysis}

MILLIPLEX ${ }^{\oplus}$ Human Cytokine/Chemokine, MMP 2 and TIMP 2 kits (Millipore, St-Quentin en Yvelines, France) were used according to manufacturer's instructions.

\section{Macrophage migration}

Migration of THP-1 cells in response to supernatant from NP-exposed macrophages was evaluated using a 24-wells Boyden chamber [57].

\section{Exposure of human fibroblasts to macrophage secretome} Human primary lung fibroblasts were obtained and cultured from a series of control subjects described in [58]. These cells were exposed to NP-exposed macrophages secretome for 48 hours. Fibroblasts expression of $\alpha$-smooth muscle actin ( $\alpha$-SMA) was then quantified, as well as their proliferation rate (Hoechst assay).

\section{Statistical analyses}

Comparisons between controls and welders were performed using Chi squared, Fisher's exact or MannWhitney nonparametric tests as appropriate (GraphPad Prism software, USA). A p $<0.05$ was considered as statistically significant.

\section{Additional files}

Additional file 1: Figure S1. MMP/TIMP levels in supernatant from THP-1 macrophages exposed for 24 hours to welding-representative NP. THP-1 were exposed to 5 or $25 \mu \mathrm{g} / \mathrm{cm}^{2}$ NP for 24 hours. Mix is a 1:1:1:1 mixture of the four NP. Macrophage pro-inflammatory secretome was assayed by Luminex. Open bars: Control. Grey bars: $5 \mu \mathrm{g} / \mathrm{cm}^{2}$. Black bars: $25 \mu \mathrm{g} / \mathrm{cm}^{2}$. $\mathrm{N}=6$ per condition. * $\mathrm{p}<0.05$ vs Control condition.

Additional file 2: Figure S2. Pro-inflammatory secretome of THP-1 macrophages exposed for 24 hours to welding-representative NP and cigarette smoke. THP-1 cells were exposed to $25 \mu \mathrm{g} / \mathrm{cm}^{2}$ NP for 24 hours in presence or in absence of $5 \%$ cigarette smoke extract (CSE). Mix is a 1:1:1:1 mixture of the four NP. Macrophage pro-inflammatory secretome was assayed by Luminex. Black bars: without CSE. Dashed bars: with CSE. $\mathrm{N}=6$ per condition. * $\mathrm{p}<0.05$ vs respective Control condition.

Additional file 3: Figure S3. MMP/TIMP levels in supernatant from THP-1 macrophages exposed for 24 hours to welding-representative NP and cigarette smoke. THP-1 cells were exposed to $25 \mu \mathrm{g} / \mathrm{cm}^{2} \mathrm{NP}$ for 24 hours in presence or in absence of 5\% cigarette smoke extract (CSE). Mix is a 1:1:1:1 mixture of the four NP. Macrophage pro-inflammatory secretome was assayed by Luminex. Black bars: without CSE. Dashed bars: with CSE. $N=6$ per condition. * $p<0.05$ vs respective Control condition.

Additional file 4: Figure S4. Quantification of macrophage migration after exposure to NP-exposed macrophage secretome. THP-1 macrophages were exposed to NP-exposed macrophage secretome in Boyden chamber. For each condition, the number of cells that have migrated to the bottom of the membrane was counted in eight fields. Mix is a 1:1:1:1 mixture of the four NP. $N=6$ per condition. $\mathrm{p}<0.05$ vs Control condition.

Additional file 5: Figure S5. Characterization of human primary lung fibroblasts response to NP-exposed macrophage secretome. A: Representative images of immunofluorescent staining for a-SMA expression in human primary lung fibroblasts in response to NP-exposed macrophage secretome. Scale bar: $50 \mu \mathrm{m}$. TGF- $ß$ was used as a positive control. B: Quantification of a-SMA expression. $\mathrm{N}=6$ per condition. C: Quantification of human primary lung fibroblasts proliferation in response to NP-exposed macrophage secretome. $\mathrm{N}=6$ per condition.

Additional file 6: Additional Methods section.

\section{Abbreviations}

NP: Nanoparticle; (S)TEM: (Scanning) transmission electron microscopy; EDX: Energy dispersive X-ray; $\mu$-XRF: X-ray microfluorescence; XRD: X-ray diffraction.

\section{Competing interests}

The authors declare that they have no competing interests.

\section{Authors' contributions}

PA, ASD, JB and SL designed the study. BC performed the face-to-face interview, PA and JCP selected the patients, and PA and FGS performed the histological analysis. MABG performed the mineralogic analyses, and ASD all biological experiments. ASD, BF, JD and SL performed the $\mu$ XRF experiments, and ASD performed all other imaging experiments. GB and OD synthesized and characterized the NP. PA, ASD and SL drafted the manuscript, and SL and $\mathrm{JB}$ were the main additional participants to its further elaboration. All authors read and approved the final manuscript.

\section{Acknowledgments}

The authors would like to thank Laurent Martinon and Xavier Janson (Laboratoire d'Étude des Particules Inhalées), Soizick Chamming's (Institut Interuniversitaire de Médecine du Travail de Paris - Ile de France) for their participation in the study, Dr Blandine Briquel-Jean-Luc for her helpful contribution to collect complete work history data of each subject, and Ali Kermanizadeh for the English editing.

This work has benefited from the facilities and expertise of the Imagif Cell Biology Unit of the Gif campus (www.imagif.cnrs.fr), which is supported by the Conseil Général de l'Essonne, and of the electronic microscopy plateform of Institut de Chimie des Matériaux Paris-Est (ICMPE, UMR 7182, Thiais, France). 
This work was supported by funds from INSERM, Chancellerie des Universités de Paris (Legs POIX), Université Paris Est-Créteil, Agence Nationale de la Recherche (grant ANR-09-CESA-017), Fond de Dotation - Recherche en Santé Respiratoire (SPLF) and C'Nano (grant AAP09-NanoSoud). Angélique Simon-Deckers and Grégory Beaune were both fellows from ANR. Jorge Boczkowski and Sophie Lanone were both recipients of a Contrat de Recherche Translationnelle, between Inserm and CHU Mondor (JB) and Inserm and CHI Créteil (SL). This work received the support of Labex SERENADE 11-LABX-0064 and form DHU A-TVB (Département Hospitalo-Universitaire Ageing-Thorax-Vessel Blood).

\section{Author details}

'Centre Hospitalier Intercommunal de Créteil, Service de Pneumologie et de Pathologie Professionnelle, 94000 Créteil, France. ${ }^{2}$ INSERM, U955, Equipe 4, 94000 Créteil, France. ${ }^{3}$ Université Paris Est-Créteil, Faculté de Médecine, 94000 Créteil, France. ${ }^{4}$ Laboratoire de Physique des Solides, CNRS UMR 8502, 91400 Orsay, France. ${ }^{5} \mathrm{CHU}$ Caen, Service d'Anatomo-Pathologie, 14000 Caen, France. ${ }^{6}$ INSERM, U1086, Faculté de Médecine, 14000 Caen, France. ${ }^{7}$ Sorbonne Universités, UPMC Univ. Paris 06, UMR 7574, Laboratoire de Chimie de la Matière Condensée de Paris, F-75005 Paris, France. ${ }^{8}$ CNRS, UMR 7574, Laboratoire de Chimie de la Matière Condensée de Paris, F-75005 Paris, France. ${ }^{9}$ Collège de France, UMR 7574, Laboratoire de Chimie de la Matière Condensée de Paris, F-75005 Paris, France. ${ }^{10} \mathrm{CHU}$ Caen, Service de Santé au Travail et Pathologie Professionnelle, 14000 Caen, France. ${ }^{11}$ Laboratoire d'Etude des Particules Inhalées, 75013 Paris, France. ${ }^{12} \mathrm{CHU}$ Henri Mondor, Service d'explorations fonctionnelles respiratoires, 94000 Créteil, France.

Received: 28 January 2014 Accepted: 18 April 2014

Published: 13 May 2014

\section{References}

1. Li JJ, Muralikrishnan S, Ng C-T, Yung L-YL, Bay B-H: Nanoparticle-induced pulmonary toxicity. Exp Biol Med 2010, 235:1025-1033.

2. Seaton A, Tran L, Aitken R, Donaldson K: Nanoparticles, human health hazard and regulation. J R Soc Interface 2010, 7(Suppl 1):S119-S129.

3. Kendall $M$, Holgate $S$ : Health impact and toxicological effects of nanomaterials in the lung. Respirology 2013, 17:743-758.

4. Taylor MD, Roberts JR, Leonard SS, Shi X, Antonini JM: Effects of welding fumes of differing composition and solubility on free radical production and acute lung injury and inflammation in rats. Toxicol Sci 2003, 75:181-191.

5. Yu IJ, Song KS, Maeng SH, Kim SJ, Sung JH, Han JH, Chung YH, Cho MH, Chung KH, Han KT, Hyun JS, Kim KJ: Inflammatory and genotoxic responses during 30-day welding-fume exposure period. Toxicol Lett 2004, 154:105-115.

6. Hamilton RF Jr, Wu N, Porter D, Buford M, Wolfarth M, Holian A: Particle length-dependent titanium dioxide nanomaterials' toxicity and bioactivity. Part Fibre Toxicol 2009, 6:35

7. Shvedova AA, Kapralov AA, Feng WH, Kisin ER, Murray AR, Mercer RR, St. Croix CM, Lang MA, Watkins SC, Konduru NV, Allen B, Conroy J, Kotchey G, Mohamed B, Meade A, Volkov Y, Star A, Fadeel B, Kagan V: Impaired clearance and enhanced pulmonary inflammatory/fibrotic response to carbon nanotubes in myeloperoxidase-deficient mice. PLOS One 2012, 7:e30923.

8. Tabet L, Bussy C, Setyan A, Simon-Deckers A, Rossi MJ, Boczkowski J, Lanone $S$ : Coating carbon nanotubes with a polystyrene-based polymer protects against pulmonary toxicity. Part Fibre Toxicol 2011, 8:3.

9. Sowards JW, Ramirez AJ, Dickinson DW, Lippold JC: Characterization of welding fume from SMAW electrodes - Part II. Welding J 2010, 89:82-90.

10. Dasch J, D'Arcy J: Physical and chemical characterization of airborne particles from welding operations in automotive plants. $J$ Occup Environ Hyg 2008, 5:444-454.

11. Stephenson D, Seshadri G, Veranth JM: Workplace exposure to submicron particle mass and number concentrations from manual arc welding of carbon steel. AlHA J (Fairfax, Va) 2003, 64:516-521.

12. Antonini JM: Health effects of welding. Crit Rev Toxicol 2003, 33:61-103.

13. Zeidler-Erdely PC, Erdely A, Antonini JM: Immunotoxicology of arc welding fume: worker and experimental animal studies. J Immunotoxicol 2012, 9:411-425.

14. Kim JY, Chen JC, Boyce PD, Christiani DC: Exposure to welding fumes is associated with acute systemic inflammatory responses. Occup Environ Med 2005, 62:157-163.
15. Fireman E, Lerman $Y$, Stark $M$, Schwartz $Y$, Ganor E, Grinberg N, Frimer R, Landau DA, Zilberberg M, Barenboim E, Jacovovitz R: Detection of occult lung impairment in welders by induced sputum particles and breath oxidation. Am J Ind Med 2008, 51:503-511.

16. Fang SC, Eisen EA, Cavallari JM, Mittleman MA, Christiani DC: Circulating adhesion molecules after short-term exposure to particulate matter among welders. Occup Environ Med 2009, 67:11-16.

17. Merigoux C, Briki F, Sarrot-Reynauld F, Salome M, Fayard B, Susini J Doucet J: Evidence for various calcium sites in human hair shaft revealed by sub-micrometer X-ray fluorescence. Biochim Biophys Acta 2003, 1619:53-58.

18. Antonini JM, Lewis $A B$, Roberts JR, Whaley DA: Pulmonary effects of welding fumes: review of worker and experimental animal studies. Am J Ind Med 2003, 43:350-360

19. Kalliomaki PL, Sutinen S, Kelha V, Lakomaa E, Sortti V: Amount and distribution of fume contaminants in the lungs of an arc welder post mortem. Br J Ind Med 1979, 36:224-230

20. Hull MJ, Abraham JL: Aluminum welding fume-induced pneumoconiosis. Hum Pathol 2002, 33:819-825.

21. Antonini JM, Roberts JR, Schwegler-Berry D, Mercer RR: Comparative microscopic study of human and rat lungs after overexposure to welding fume. Ann Occup Hyg 2013, 57:1167-1179.

22. Stern RM, Pigott GH, Abraham JL: Fibrogenic potential of welding fumes J Appl Toxicol 1983, 3:18-30.

23. Abraham JL, Burnett BR: Quantitative analysis of inorganic particulate burden in situ in tissue sections. Scan Electron Microsc 1983, Pt2:681-696.

24. Abraham JL, Hunt A, Burnett B: Steel (Fe-Cr) Particles as a marker of welding fume exposure, frequency of occurrence and prevalence in a series of over 400 human lungs. Ann Occup Hyg 1994, 38:551-557.

25. Abraham JL, Hunt A, Burnett BR: Lung pathology and mineralogy associated with high pulmonary burden of metal particles: $\mathrm{Fe}, \mathrm{Ti}, \mathrm{Al}$ and $\mathrm{Cr}$ in a pneumoconiosis database. Ann Occup Hyg 1997, 41:522-530.

26. Guidotti TL, Abraham JL, DeNee PB, Smith JR: Arc Welders' pneumoconiosis: application of advanced scanning electron microscopy. Arch Environ Health 1978, 33:117-124.

27. Sowards JW, Lippold JC, Dickinson DW, Ramirez AJ: Characterization of welding fume from SMAW electrodes - Part I. Welding J 2008, 87:106-112.

28. Stettler LE, Groth DH, Mackay GR: Identification of stainless steel welding fume particulates in human lung and environmental samples using electron probe microanalysis. Am Ind Hyg Assoc J 1977, 38:76-82.

29. Keane M, Stone S, Chen B: Welding fumes from stainless steel gas metal arc processes contain multiple manganese chemical species. J Environ Monit 2010, 12:1133-1140.

30. Jenkins N, Eagar TW: Chemical analysis of welding fume particles. Welding J 2005, 84:87s-93s

31. Flynn MR, Susi P: Manganese, iron, and total particulate exposures to welders. J Occup Environ Hyg 2009, 7(2):115-126.

32. Driscoll K: Macrophage inflammatory proteins : biology and role in pulmonary inflammation. Exp Lung Res 1994, 20:473-490.

33. Larsson K: Inflammatory markers in COPD. Clin Respir J 2008, 2(Suppl 1):84-87.

34. Gales D, Clark C, Manne U, Samuel T: The Chemokine CXCL8 in Carcinogenesis and Drug Response. ISRN Oncol 2013, 2013:859154.

35. Zimmermann HW, Trautwein C, Tacke F: Functional role of monocytes and macrophages for the inflammatory response in acute liver injury. Front Physiol 2012, 3:56.

36. Driscoll K: TNFa and MIP-2: role in particule-induced inflammation and regualtion by oxidative stress. Toxicol Lett 2000, 112-113:177-184.

37. Zeidler-Erdely P, Kashon M, Battelli L, Young S-H, Erdely A, Roberts J, Reynolds $\mathrm{S}$, Antonini J: Pulmonary inflammation and tumor induction in lung tumor susceptible A/J and resistant C57BL/6 J mice exposed to welding fume. Part Fibre Toxicol 2008, 5:12.

38. Antonini J, Roberts J, Stone S, Chen B, Schwegler-Berry D, Chapman R, Zeidler-Erdely P, Andrews R, Frazer D: Persistence of deposited metals in the lungs after stainless steel and mild steel welding fume inhalation in rats. Arch Toxicol 2011, 85:487-498.

39. Antonini JM, Clarke RW, Krishna Murthy GG, Sreekanthan P, Jenkins N, Eagar TW, Brain JD: Freshly generated stainless steel welding fume induces greater lung inflammation in rats as compared to aged fume. Toxicol Lett 1998, 98:77-86.

40. Antonini JM, Krishna Murthy GG, Rogers RA, Albert R, Ulrich GD, Brain JD: Pneumotoxicity and pulmonary clearance of different welding fumes after intratracheal instillation in the rat. Toxicol Appl Pharmacol 1996, 140:188-199. 
41. Antonini JM, Roberts JR, Chapman RS, Soukup JM, Ghio AJ, Sriram K: Pulmonary toxicity and extrapulmonary tissue distribution of metals after repeated exposure to different welding fumes. Inhal Toxicol 2010, 22:805-816.

42. Antonini JM, Stone S, Roberts JR, Chen B, Schwegler-Berry D, Afshari AA, Frazer DG: Effect of short-term stainless steel welding fume inhalation exposure on lung inflammation, injury, and defense responses in rats. Toxicol Appl Pharmacol 2007, 223:234-245.

43. White AF, Peterson ML, Hochella MF Jr: Electrochemistry and dissolution kinetics of magnetite and ilmenite. Geochim Cosmochim Acta 1994, 58:1859-1875.

44. Yang H, Zhang C, Shi X, Hu H, Du X, Fang Y, Ma Y, Wu H, Yang S: Water-soluble superparamagnetic manganese ferrite nanoparticles for magnetic resonance imaging. Biomaterials 2010, 31:3667-3673.

45. Jolivet J-P, Chaneac C, Tronc E: Iron oxide chemistry. From molecular clusters to extended solid networks. Chem Commun 2004, 481-483.

46. Dorovskikh IV, Gorichev IG, Batrakov W, Kurilkin W, Izotov AD: Effect of the anionic composition and $\mathrm{pH}$ on the dissolution kinetics of chromium(III) oxide and chromium(III) hydroxide oxide in acids. Russ J Inorg Chem 2006, 51:143-151.

47. Kostka JE, Nealson KH: Dissolution and reduction of magnetite by bacteria. Environ Sci Technol 1995, 29:2535-2540.

48. Novak ML, Koh TJ: Macrophage phenotypes during tissue repair. J Leukoc Biol 2013, 93:875-881.

49. van Dijk WD, Gopal S, Scheepers PT: Nanoparticles in cigarette smoke; real-time undiluted measurements by a scanning mobility particle sizer. Anal Bioanal Chem 2011, 399:3573-3578.

50. Araya J, Nishimura SL: Fibrogenic reactions in lung disease. Annu Rev Pathol 2010, 5:77-98.

51. Camara J, Jarai G: Epithelial-mesenchymal transition in primary human bronchial epithelial cells is Smad-dependent and enhanced by fibronectin and TNF-alpha. Fibrogenesis Tissue Repair 2010, 3:2.

52. Lopez CF, Nielsen SO, Ensing B, Moore PB, Klein ML: Structure and dynamics of model pore insertion into a membrane. Biophys $J$ 2005, 88:3083-3094

53. Ishida Y, Kimura A, Kondo T, Hayashi T, Ueno M, Takakura N, Matsushima K, Mukaida N: Essential roles of the CC chemokine ligand 3-CC chemokine receptor 5 axis in bleomycin-induced pulmonary fibrosis through regulation of macrophage and fibrocyte infiltration. Am J Pathol 2007, 170:843-854

54. Roggli VL, Gibbs AR, Attanoos R, Churg A, Popper H, Cagle P, Corrin B, Franks TJ, Galateau-Salle F, Galvin J, Hasleton PS, Henderson DW, Honma K Pathology of asbestosis- An update of the diagnostic criteria: report of the asbestosis committee of the college of american pathologists and pulmonary pathology society. Arch Pathol Lab Med 2010, 134:462-480.

55. Billon-Galland MA: Exposition markers: mineralogical analysis in the sputum and the bronchoalveolar lavage-asbestos bodies-uncoated fibres. Rev Mal Respir 2012, 29:521-528.

56. Lanone S, Rogerieux F, Geys J, Dupont A, Maillot-Maréchal E, Boczkowski J, Lacroix G, Hoet PH: Comparative toxicity of 24 manufactured nanoparticles in human alveolar epithelial and macrophage cell lines. Part Fibre Toxicol 2009, 6:14.

57. Wagsater D, Zhu C, Bjorck HM, Eriksson P: Effects of PDGF-C and PDGF-D on monocyte migration and MMP-2 and MMP-9 expression. Atherosclerosis 2009, 202:415-423.

58. Dagouassat M, Gagliolo JM, Chrusciel S, Bourin MC, Duprez C, Caramelle P, Boyer L, Hue S, Stern JB, Validire P, Longrois D, Norel X, Dubois-Rande JL, Le Gouvello S, Adnot S, Boczkowski J: The cyclooxygenase-2-prostaglandin E2 pathway maintains senescence of chronic obstructive pulmonary disease fibroblasts. Am J Respir Crit Care Med 2013, 187:703-714.

doi:10.1186/1743-8977-11-23

Cite this article as: Andujar et al:: Role of metal oxide nanoparticles in histopathological changes observed in the lung of welders. Particle and Fibre Toxicology 2014 11:23.

\section{Submit your next manuscript to BioMed Central and take full advantage of:}

- Convenient online submission

- Thorough peer review

- No space constraints or color figure charges

- Immediate publication on acceptance

- Inclusion in PubMed, CAS, Scopus and Google Scholar

- Research which is freely available for redistribution

Submit your manuscript at www.biomedcentral.com/submit 